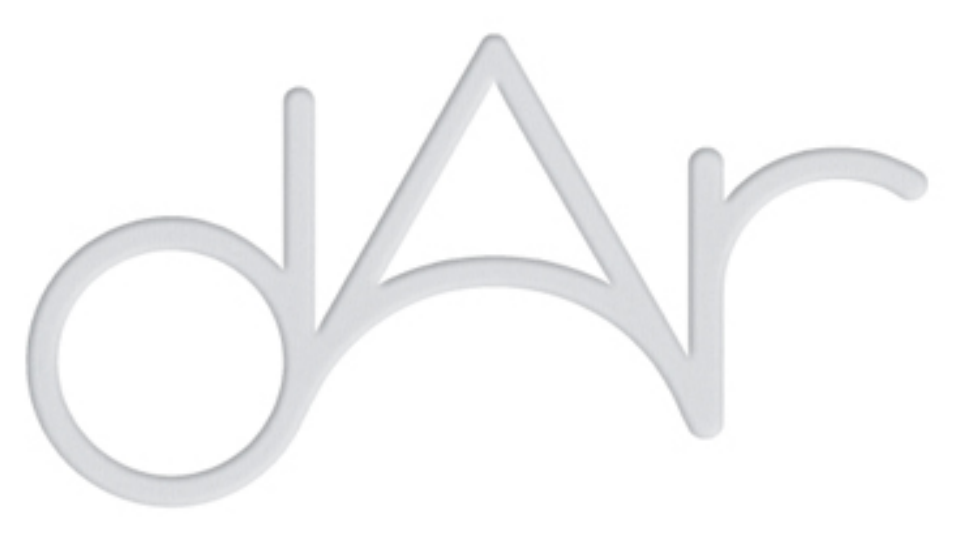

\title{
Damage in Historic Rammed Earth Structures: a Case Study at Ambel, Zaragoza,
} Spain

\author{
Autor(es): $\quad$ Jaquin, Paul; Gerrard, Christopher; Augarde, Charles; Canivell, Jacinto \\ Publicado por: CEAUCP \\ URL \\ persistente: URI:http://hdl.handle.net/10316.2/9122 \\ DOI: $\quad$ DOI: http://dx.doi.org/10.14195/2182-844X_1_4 \\ Accessed : $\quad$ 26-Apr-2023 14:21:29
}

A navegação consulta e descarregamento dos títulos inseridos nas Bibliotecas Digitais UC Digitalis, UC Pombalina e UC Impactum, pressupõem a aceitação plena e sem reservas dos Termos e Condições de Uso destas Bibliotecas Digitais, disponíveis em https://digitalis.uc.pt/pt-pt/termos.

Conforme exposto nos referidos Termos e Condições de Uso, o descarregamento de títulos de acesso restrito requer uma licença válida de autorização devendo o utilizador aceder ao(s) documento(s) a partir de um endereço de IP da instituição detentora da supramencionada licença.

Ao utilizador é apenas permitido o descarregamento para uso pessoal, pelo que o emprego do(s) título(s) descarregado(s) para outro fim, designadamente comercial, carece de autorização do respetivo autor ou editor da obra.

Na medida em que todas as obras da UC Digitalis se encontram protegidas pelo Código do Direito de Autor e Direitos Conexos e demais legislação aplicável, toda a cópia, parcial ou total, deste documento, nos casos em que é legalmente admitida, deverá conter ou fazer-se acompanhar por este aviso.

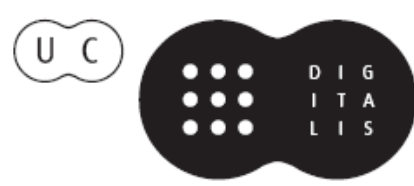


$6^{\circ}$ Seminário de Arquitectura em Terra em Portugal ( $6^{\circ}$ ATP) $9^{\circ}$ Seminário Ibero-americano de Construção e Arquitectura com Terra (9 SIACOT)

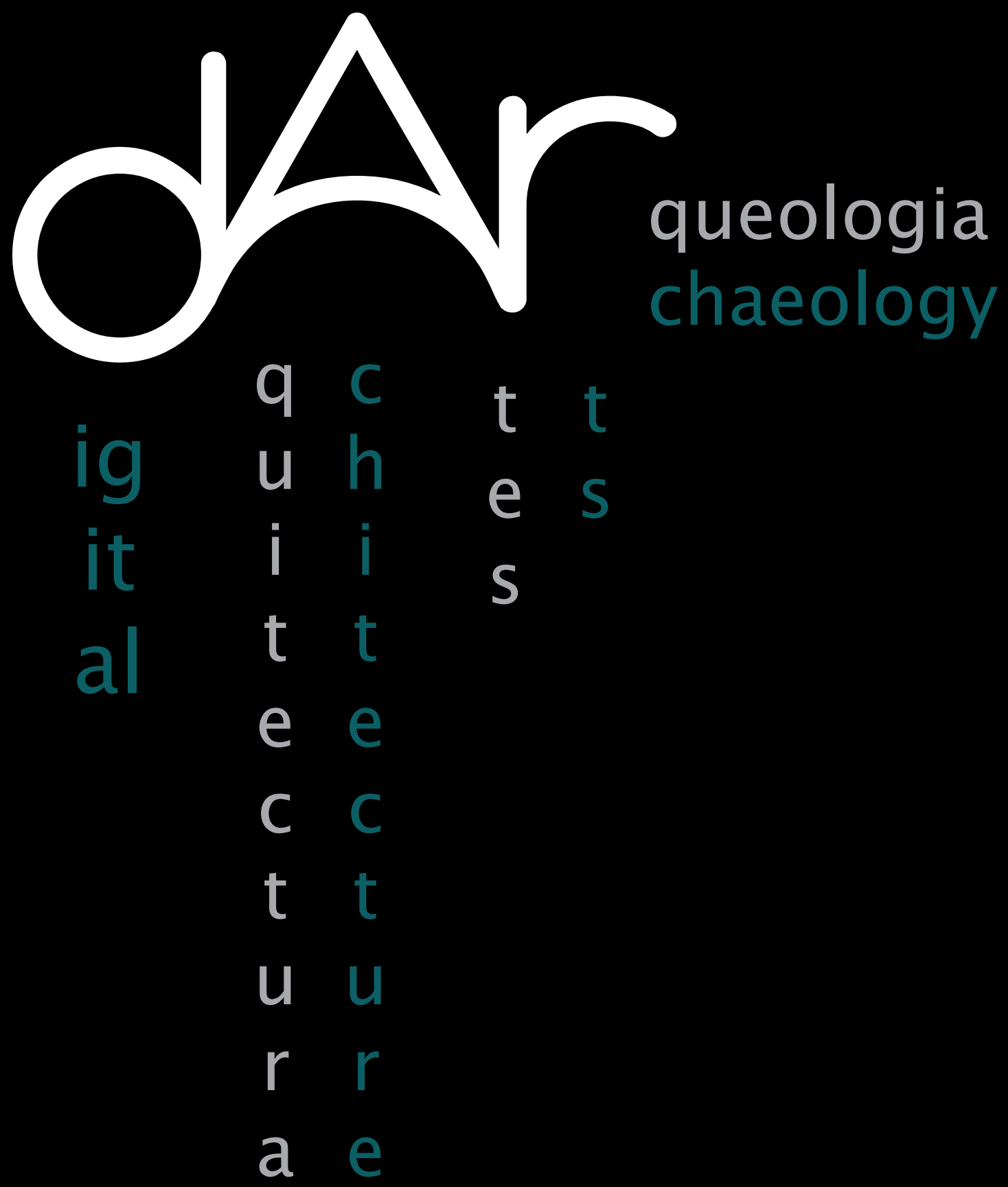




\title{
DAMAGE IN HISTORIC RAMMED EARTH STRUCTURES: A CASE STUDY AT AMBEL, ZARAGOZA, SPAIN
}

Paul Jaquin* (United Kingdom)

Integral Engineering Design

Christopher Gerrard** (United Kingdom)

Department of Archaeology, University of Durham

Charles Augarde*** (United Kigdom)

School of Engineering and Computing Sciences, University of Durham

Jacinto Canivell**** (Spain)

Escuela Universitaria de Arquitectura Técnica, Sevilla

\begin{abstract}
This paper examines the possible causes of damage to historic rammed earth structures based on a case study of a medieval and later building, formerly a preceptory of the Military Orders, in the village of Ambel in Aragon, north-east Spain. Structural and water-based mechanisms of damage are reviewed and an engineering basis for the cause of damage is proposed. Since a number of repair strategies have already been attempted on this structure, their effectiveness is also discussed. A four storey granary at the north-east corner of the preceptory complex is described in detail since it encapsulates many damage mechanisms and repair strategies which are common to historic rammed earth. The granary tower has a random rubble foundation, which is probably in part the remains of previous building, with rammed earth walls for the three storeys above. This rammed earth was originally rendered and scored to imitate fired brick but almost all of this has now fallen away. The gable end of the building has fired brick quoins, and now leans outwards slightly at the head of the wall. There is evidence of water damage because the building was neglected in the past, though not enough to initiate collapse. Structural and water based damage mechanisms are identified, and example repair strategies used at Ambel are described.
\end{abstract}

Keywords: rammed earth, building failure, unsaturated soil.

*paul.jaquin@ramboll.com

**c.m.gerrard@dur.ac.uk

***charles.augarde@dur.ac.uk

****jacanivell@us.es 


\section{INTRODUCTION}

Rammed earth is an ancient construction technique which involves the manual compaction of soil, and sometimes other added ingredients (such as lime or straw), between formwork boards to create a homogenous mass wall. The soil is compacted moist and the formwork then removed to allow the wall to dry. Rammed earth has a long history in Spain, being used as early as the Bronze Age and particularly during the time of the medieval Islamic dynasties who brought their construction techniques to Spain after the 8th century AD (Jaquin, Augarde et al., 2008).

The preceptory at Ambel has been intensively recorded and studied (Gerrard 1999; Gerrard 2003) and is used as the case study in this paper. The site served as an administrative centre by the Templar Order immediately after the Christian 'reconquest' of the area in the early 12th century and, when the Templars were dissolved at the turn of the 14th century, the building and its estate passed to another Military Order, the Hospitallers (later popularly known as the Knights of Malta). The complex which survives today was built in a series of phases over a period of 300 years, probably by local Muslim craftsmen. This paper details only part of the whole complex and focuses on what is now a four-storey granary at the north-east corner of the site (Fig. 1). This building has significant structural problems and is in need of both investigation and remediation.

The basement today is a wine and storage cellar of stone and brick, and there are clues here to several generations of structural alteration and repair. Detailed recording of the standing building suggests that the first phase of construction still visible on this part of the site was a substantial 14th century wall (1,9 $\mathrm{m}$ thick at the base battered to $0,90 \mathrm{~m}$ at the top) which ran along the northern perimeter of the precinct. Its date is suggested by surviving decorative brickwork. At a later date this wall was incorporated into a multi-storey structure, of which only fragments remain including the butt of a brick springer arch and an arrow loop. The dates for this lost construction are imprecise but must lie somewhere in the period 13401569; the arrow loop, a feature of military fortifications, suggests a date around 1357-1369 when castles on the frontier with Castile were strengthened. The fate of this building, presumably a tower of some sort, is unknown; it may have collapsed since the structure which can be seen today stands on its footprint. What survives today is most of the foundation of that earlier structure with three new floor levels above which were constructed around 1569 (Gerrard, 2003, pp. 191-201). The first and second floors are built in rammed earth and were used as granaries. Graffiti on the walls and documentary evidence shows that they held quantities of cereals such as wheat, rye and barley (Gerrard, 2003, pp. 323-328). The third floor was an attic space where air circulated through galleries of arches, an architectural feature typical of Aragonese 16 th century palaces. A fourth floor, now entirely lost, is thought to have been an arched brick turret above the northern end of the structure.

The building fabric of these four storeys reveals a long history of damage, repair and alteration. A change in floor tiling pattern; newer columns and ceiling beams on the floor below suggest a collapse of the first floor. This was perhaps due to excessive loading on that storey, which could easily occur if the room was filled with grain (Fig. 3). There is evidence for a multitude of repairs to the north wall of the structure, with timber tie beams inserted in the walls at the first and third floor levels. By 1797 the building had fallen into disrepair, and major alterations were carried out. A tower at the south east and the fourth floor brick turret were removed. The roof was replaced using the typical split bamboo mats covered by a spread of soil and clay tiles (Fig. 1). There is evidence of attempted repairs to correct the lean of the north gable wall, with ceiling jack arches and beams being replaced. Access to this wing of the complex was re-arranged - on the eastern side of the basement there is a blocked archway in the east wall, formerly the main entrance at this level, and an abandoned water channel $(0,70 \mathrm{~m}$ wide) is partly exposed here. This water channel, which once ran through the 
basement, was diverted to run outside the building, as it still does today.

Today there are two independent sets of cracks in the east elevation (Fig. 1) - two slightly inclined cracks in the centre of the building; and two vertical cracks at the north end of the east elevation, which are related to the lean of the north gable end wall. This wall leans outwards from ground level to mid-height of the second storey, with the section above this being built vertically on top of a leaning wall. The current owners of the building installed crack monitoring points in the early 1990 s and this monitoring shows the continued opening of the cracks at the northern end of the tower. As a result, of rammed earth (Walker, Keable et al., 2005) when compared to fired masonry and or unreinforced concrete means that relatively minor issues can result in major structural problems. The particular vulnerability of unstabilised rammed earth to water means that there is a coupling of structural and water based issues which does not occur in non-earthen structures. This means that problems caused by water may become structural problems, while structural problems may allow water ingress to a structure causing further damage. This paper separates these two issues, while still acknowledging the coupled nature of problem.

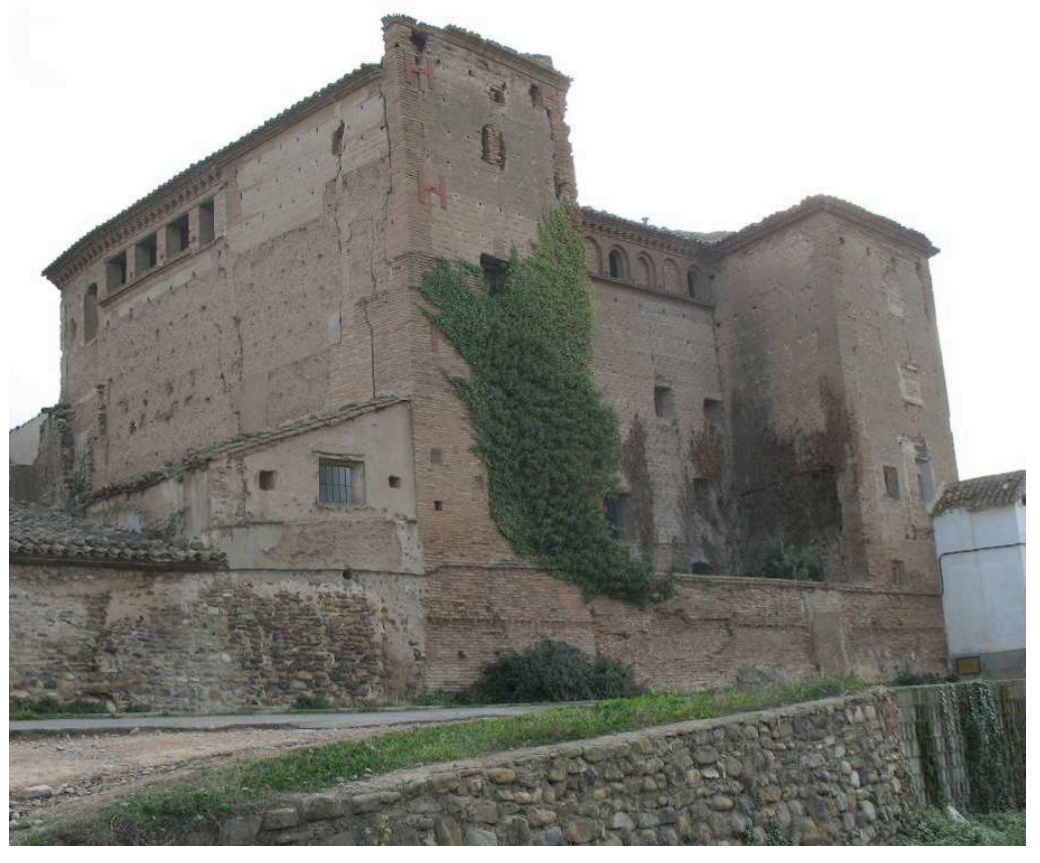

Fig. 1. The preceptory at Ambel, north-east elevation. The gallery of arches between the towers is typical of 16th century architecture in this region. The first phase precinct wall reaches the base of ivy and stands $3 \mathrm{~m}$ high.

tie bars were placed at ceiling level at the ground, first and second storeys in 2000. These are fixed internally by bolting onto the ceiling beams and protrude externally to link to $\mathrm{H}$-shaped bars on the facade which were positioned so as to overlap the brick quoins (Fig. 1).

\section{STRUCTURAL}

Structural problems are common to all building materials, but the perceived low tensile and assumed zero shear strength

\subsection{Causes of structural damage}

There are a wide range of causes of structural problems, including ground movement, failure or inadequacy of building elements, incorrect design, or excessive loading. This paper focuses on those issues which are felt to be specific to rammed earth. Fig. 2 shows some of the mechanisms which have been identified. Potential causes of structural problems are shown in bold, while their effects are shown in a normal font. The numbers 1 and 2 in italics refer to positions where opening or cracking may 
occur. Three particular issues with rammed earth in Spain are identified; the interface between brick and rammed earth, joints between adjacent rammed earth blocks and transverse beams or lintels bearing onto ineffective or absent wall plates.

One feature of medieval Spanish architecture is the use of rammed earth fill between fired brick columns (Jaquin, 2008a). Inspection of a number of such joints between the brick and the rammed earth this separation (which would appear as cracking in a homogeneous material) takes place at the weakest point. As a butted vertical joint between two rammed earth blocks cannot carry any tensile stress, the join between the blocks will then open.

To prevent localised shear failure of the wall beneath a load bearing transverse beam, wall plates are used to spread the load over a larger area. Where such wall plates are absent, either through poor initial design
Fig. 2. Examples of failures of structural elements

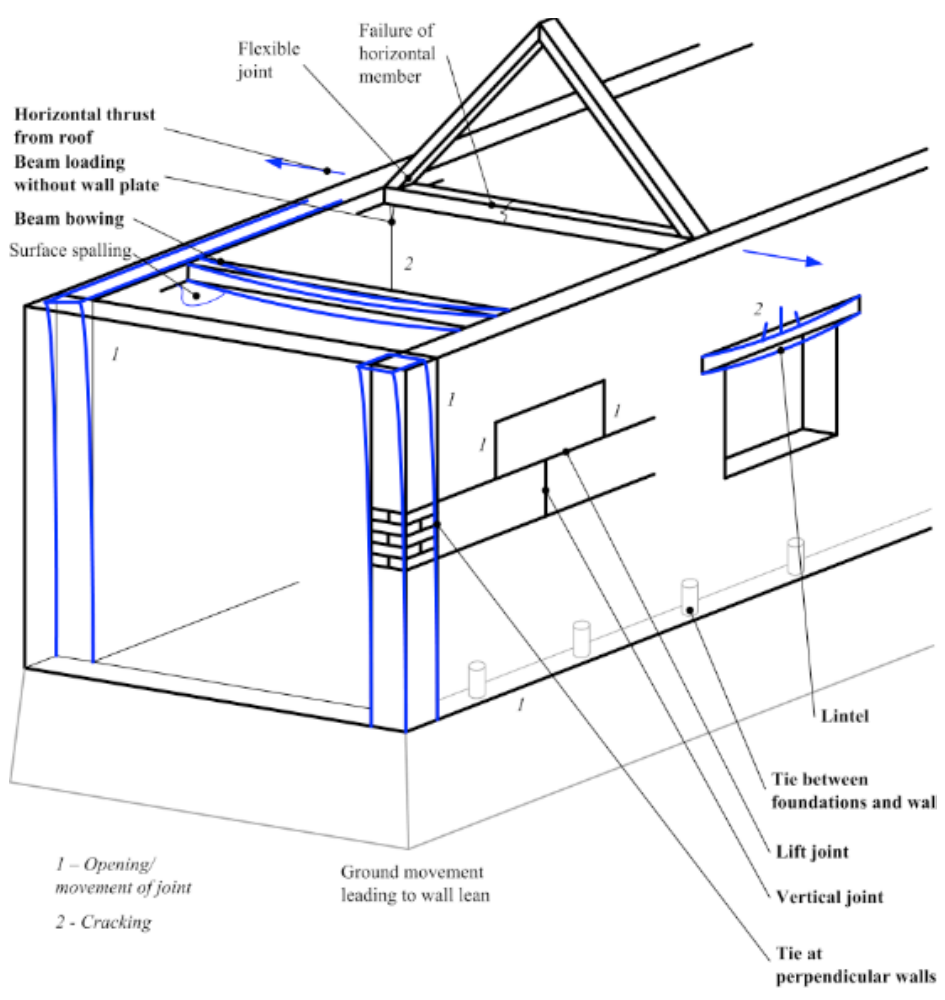

or later alteration to the structure, there is the potential for shear failure of the wall beneath the loaded beam. Out of plane failure can also occur where a beam joining a wall is insufficiently stiff and bows under loading. This causes an increased load at the face of the wall, and can lead to spalling of the material at the face (Fig. 2).

\subsection{Structural repair strategies}

At a whole building scale, two broad categories for structural repair can be defined, namely hard and soft. Hard repair involves a deliberate increase in strength and stiffness of a section of the building, and should be used where the underlying cause of the structural problem has not 
been fully addressed. Soft repairs aim to replace the fabric of the structure, and should be undertaken when the cause of the structural problem has been mitigated. Hard repairs often involve the placement of steel or timber, whereas soft repairs tend to use material similar to that of the building. The concept of a 'soft' crack stitch has been employed at Basgo, India (Jaquin, 2008b) which creates a staple using a similar material to that of the wall. This method attempts to match the material properties (stiffness, thermal expansion) of the stitch and the wall, allowing the stitch to become an integral part of the wall and thereby restoring some structural continuity across the crack.

\subsection{Case study of Ambel - structural}

The gable end wall of the north-east granary at Ambel is showing a significant outward lean at the head of the wall, and monitoring of the cracking patterns shows that the cracks continue to open. The cause of this lean is assumed to be an ineffective retaining wall to the north of the gable wall, allowing continued settlement of the ground. The nature of the foundations of the tower is not known. As it is not currently possible to reinstate this wall, or to upgrade the road, hard intervention techniques have been used.

In the late 18th century a number of hard repair measures were already being enacted at to prevent collapse of the leaning north wall. There is no structural tie between the rammed earth north and east walls, and the brick quoin at the corners. As described above, a further storey tower may have existed at the north of the granary, and this tower may have provided a structural tie between the gable end and the transverse walls. Analysis of the architectural fabric suggests that timber buttressing was placed against the external wall, and repairs were carried out to the ceiling arches at each floor. In addition, battens were embedded at the north end of the east and west walls, spanning to the leaning north wall. Their effectiveness is questionable, as cracks are present in the wall at the south end of these timbers. This indicates that the timbers may have succeeded in stiffening the north end of the structure, but because ground movement has not been halted, further deformation and cracking has occurred. In $2000 \mathrm{H}$-shaped spreader plates were fixed to the face of the wall, which are affixed to $150 \mathrm{~mm} \times 80 \mathrm{~mm}$ l-beam sections running through the length of the building. These I-sections are bolted to the transverse ceiling timbers at each side of the building at ground, first and second floor levels.

Although this intervention follows sensible principles, it may be noted that the horizontal component of the lean of the gable wall is transferred directly to the transverse timbers through bolting, which maybe prove unsatisfactory, with the bolts shearing from the timber with increased horizontal load from the gable wall. Monitoring of crack growth shows that the placement of this system has not arrested the growth of the cracks, suggesting that it is yet to engage or is proving ineffective. Future work is now being suggested which will involve the placement of spreader plates on the outside of the south wall, allowing the I-beam sections to span the whole length of the building and thereby stiffen the whole structure.

Where the cause of the structural problem has been mitigated, then a soft repair of filling of the cracks is recommended. This will not only improve the appearance of the building but also prevent water ingress. At Ambel, cracks in the centre of the long east wall are thought to have formed prior to the movement of the gable end, and have therefore been filled. The filler is brick, which would originally have matched the scored rendered original face of the rammed earth, although this is now removed. Filling with similar fallen material in rammed earth is problematic, though the column method is recommended by Pearson (1997) and other possibilities are suggested in Jaquin (2008a).

Reinstatement of the roof of the granaries occurred around the same time as the late 18th century repairs. At one location this involved the introduction of a transverse timber beam which carries a large proportion of the roof loading into the south 
gable end wall. This timber is causing inplane cracking of the rammed earth wall because of the lack of a wall plate. maintain the vertical faces required for walls, and rests at its angle of friction.

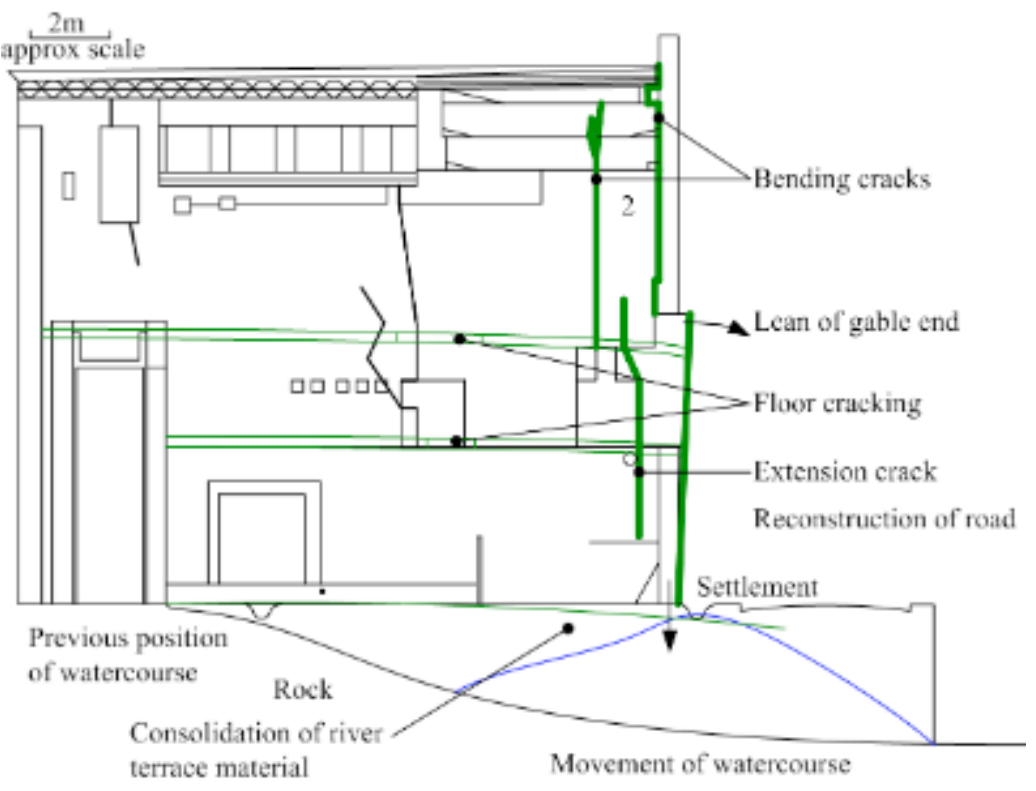

Fig. 3. Cracking patterns and causes, east-facing elevation of the north-east tower at Ambel
This case study structure shows that although localised failure may occur, there may be phases of rebuilding on surviving rammed earth following partial collapse. The evident lack of understanding of the properties of the building material is shown in the 19th century repairs. Sadly, these 'repairs' are often part of the problem rather than the solution.

\section{WATER}

The poor resistance of rammed earth to water penetration is highlighted by comments made by a French officer defending rammed earth castles in Morocco in 1956 - "It's not their guns I'm frightened of, but God help us if they use water pistols" (Maxwell, 2000). In more technical terms, the strength of unstabilised rammed earth is due to the presence of bridges of water between the soil grains, and as such it may be treated as a highly unsaturated soil (Jaquin, Augarde et al., 2009). When the soil becomes saturated, these bridges are removed and the rammed earth loses its strength and behaves as a purely frictional material. It is then unable to

\subsection{Damage mechanisms}

Jaquin, Augarde et al. (2009) showed that an increase in the water content of rammed earth reduces its strength and stiffness and increases its ductility. It was argued in that paper that unstabilised rammed earth may be described as a highly unsaturated. The term 'unsaturated' describes soil where both air and water are present in the pores between the soil particles. At the interface of the air and the water there exists a meniscus which acts as a sheet in uniform tension, giving rise to the phenomenon of surface tension. This meniscus holds the water in the pores at lower than atmospheric pressure, and the combination of the lower pressure of the pore water and the tension of the meniscus combine to provide an attractive force across the pore between the soil particles. This attractive force provides the soil with increased strength and stiffness over a saturated or completely dry soil where the pores are completely filled with water or air respectively. Jaquin, Augarde et al. (2009) showed that the (negative) pressure of the water in the pores (termed suction) is related to the strength and stiffness of unstabilised 
rammed earth samples. The strength and stiffness of rammed earth will reduce when the soil becomes saturated and the attractive force between the soil particles provided by the liquid bridges is lost. The size and strength of the liquid bridges is a function of the relative humidity of the air in the pores of the rammed earth wall, with increasing relative humidity leading to reduced strength of the liquid bridges and therefore of the rammed earth. Heath, Lawrence et al. (2009) showed that even at $100 \%$ relative humidity, rammed earth samples do not become saturated and lose all their strength. It is proposed that water running over the surface of a wall, allowing constant infiltration causes erosion of rammed earth. Damage to unstabilised rammed earth caused be water is a result of it becoming saturated. A number of mechanisms by which water can enter a structure are shown in Fig. 4. This paper argues that it is the magnitude of the water infiltration which causes damage to rammed earth.

The impact of rain against the face of a rammed earth wall is often described as a mechanism by which walls erode, and therefore extended eaves are required to prevent falling water from impacting the surface of the wall (e.g. Walker, Keable et al., 2005). However, it is proposed that is the rate at which water is allowed to enter a wall which determines if erosion of the wall occurs. The infiltration of a single raindrop into the face of a wall will raise the relative humidity of the wall by a small amount, but this increase in humidity is spread through the whole thickness of the wall, meaning that it takes a long time for the relative humidity of the pores in the wall to reach 100\%. Heath, Lawrence et al. (2009) show that a wall remains unsaturated is in a $100 \%$ relative humidity environment, and physical application of water is required to raise the water content of the wall further. Warren (1993) and Hall and Djerbib (2006) describe 'overcoat' regions of saturated material at the face of the wall, which prevent further water ingress. However, this is assumed to be incorrect, as a saturated region would lose all strength from liquid bridges and behave as a frictional material, resting at its angle of repose.

Water does pose a problem for unstabilised rammed earth structures where it is allowed

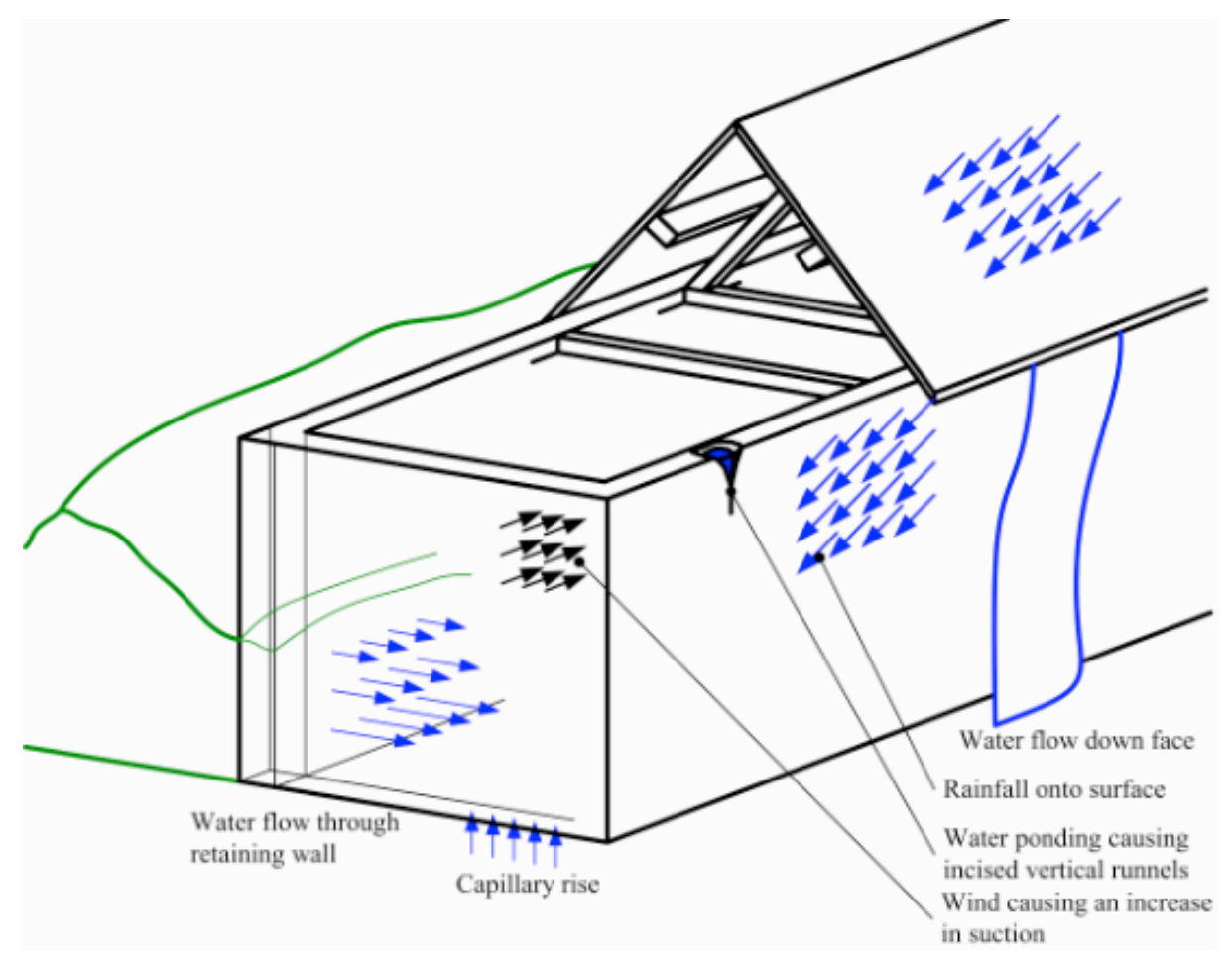

Fig. 4. Causes of damage by water 
to flow down the surface of a wall. This usually happens where it is allowed to gather (pond) at the head of a wall, and flow down the face. Because of the larger volumes of water involved, the rate of water infiltration overtakes the rate at which water is removed from the wall by evaporation, and so a drip forms on the surface of the wall. This may allow the surface of the rammed earth to become saturated, and for soil particles to become suspended within the liquid and flow. This mechanism can be seen in the formation of worm cast type structures where material has first flowed into a slurry, then dried to leave mounds of fine material on the wall face. The presence of these structures indicates the downward movement of material and is thus indicative of past water flow. The likely cause of the formation of the structures is the slow downward movement of water down the face of a wall, for example a drip which is able to pick up material and transport it in solution down the wall, until such a point as the drip evaporates and the material is returned to the wall. Inspection of these structures indicates that they contain only very small particles, as it is only these which may be picked up by the water. The rate of infiltration of water into the body of the wall is sufficiently slow that the drip of water is able to continue down the face of the wall, saturating and therefore picking up smaller soil particles, before all the water is absorbed by capillary action into the wall and those smaller soil particles redeposited. If the rate of water flow is increased, such as by an ineffective drain, then larger soil particles and larger volumes of material are picked up by the water flow, and incisions form in the vertical face of the wall (Fig. 4).This mechanism involves the movement of material down the wall causes a deterioration of the structure.

\subsection{Repair strategies - water}

Repair of rammed earth walls damaged by water should only be attempted when the cause of the water flow has been addressed. It has been argued that the main repair strategy for water damage is reinstatement of the head of the wall to prevent further water flow down the face. This has taken the form of concrete ring beams for the restoration of the towers at Biar and La Rambla (Jaquin, 2008a) or as bamboo matting at Ait Ben Haddou in Morocco. If it is possible, then the roof of the structure must be reinstated, and the drainage from this correctly positioned.

Repair of the face of a wall, where damaged by water, should involve reinstatement with the fallen or similar material which will provide similar material properties (stiffness, permeability and shrinkage) as the rest of the wall. There are many examples of the repair of rammed earth buildings using a less permeable render such as cement (see Jaquin, 2008b). While this render reduces the flow of water into the wall, it also reduces the flow of water out of the wall. If water is able to enter the wall by any other means (for example through capillary rise), and is not able to escape (water only flows upwards by capillary rise), then there is an increase in water content of the wall. This leads to a loss of strength and stiffness, and the wall will fail, either through a the build up of water behind a less permeable render, or by becoming saturated and losing strength and stiffness.

\subsection{Case study of Ambel - water}

The north-east tower at Ambel has suffered

Fig. 5. Worm cast type structures visible at Ambel beneath a previously damaged roof section

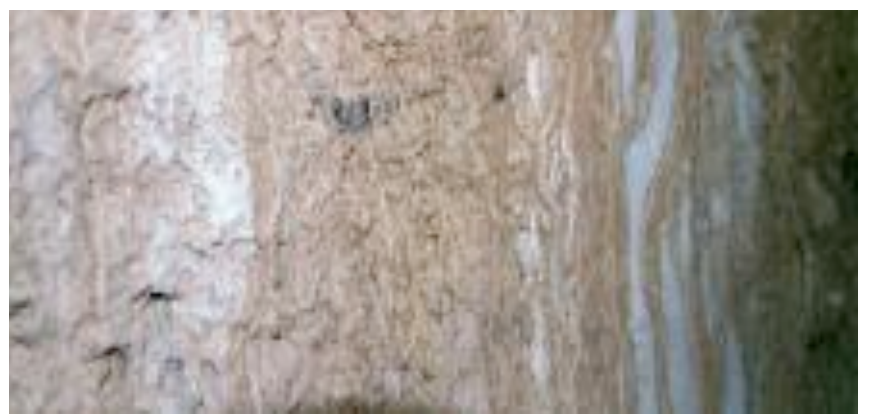


significant neglect at periods through its history, and shows some evidence of water damage. The roof has now been repaired and seems to be effective, though some evidence of water damage remains.

Where water has been allowed to gather and run down the face of a wall, cast structures, such as described in Section 4.1, are observed on the face of the wall (Fig. 5). However, these have served as a forewarning of further damage and caused the building owners to undertake repairs. As a result, there are no deep incisions into the rammed earth as shown in Fig. 4, and as observed at other historic rammed earth sites (Jaquin, 2008b). However, the eaves do not protrude on any of the faces, and this may have allowed a water flow down the face of the wall. If water is allowed to gather behind the render, then the rammed earth may become locally saturated, meaning the liquid bridges providing a bond between the render coat and the rammed earth may become saturated, causin the render to spall away from the wall (Fig. 1).

There has been no rendering of the Ambel tower using cement, the only surface covering is plaster on the interior walls. As a result the building remains structurally sound. This is in contrast to other rammed earth buildings in the village of Ambel which have been periodically repaired with impermeable renders. In many cases the damage is minor but the visual impact is unsightly and can add to the negative image sometimes associated with decay of ancient buildings.

The mortared rubble foundation of the rammed earth granaries has served to prevent capillary rise of water into the rammed earth, and therefore the rammed earth at Ambel has never been subject to increases in water content, other than caused by rain water impact or ineffective roof drainage.

\section{CONCLUDING REMARKS}

Many rammed earth buildings are now considered to be of great cultural value. The repair of such structures should ideally be conducted only after recording and analysis. Repair strategies must be determined based on the cause of damage, and that must be rectified before repair work begins. The vulnerability of earthen structures to water means that there is often a coupling of the damage mechanisms, and there must also be a doubling up of the repair strategies, ensuring both that the current damage is mitigated, and that no further damage will occur.

This paper has argued that the causes of structural problems should be addressed prior to repair and has introduced the notion of hard and soft repairs. Where it is impossible to address the cause of the problem, then hard repairs to increase the strength and stiffness of the structure should be used. In the case of rammed earth this is currently problematic, with little known about the strength and stiffness characteristics of historic rammed earth. If the cause of the structural problems has been remedied, then soft repairs can be enacted. Soft repairs restore the integrity of the building and should be done using similar or fallen material from the wall.

The role of water in causing damage to historic rammed earth structures has been discussed and it is proposed that the rate of water flow defines if damage will occur to a historic structure. If the rate is sufficiently low, such as is caused by rainfall impact, then significant damage will not occur. If, however an ineffective roof or drainage is present, then the localised flow of water may increase, leading to erosion. Where this is prevented from happening, damage does not occur. Large overhanging eaves are not present on Ambel's north-east tower, and their absence may have allowed decay of the render, but the building remains sound as an adequate drainage system prevents water from flowing down the face.

The case of Ambel has proved useful in highlighting the holistic approach which is required when conserving historic earth buildings. A detailed understanding of both the current state of the building and the phases of its construction is required before conservation work should be undertaken. 
This is achieved through systematic survey of the existing structure and detailed understanding of the history through the review of documentary and archaeological evidence to allow the creation of a 'building biography'. Only with such understanding can engineers hope to understand the state of the existing building and provide advice on the structural and fabric repairs which may be required.

\section{Bibliography}

Gerrard, C. M. (1999). Opposing identity: Muslims, Christians and the Military Orders in Rural Aragon. Medieval Archaeology XLIII, 143-160.

Gerrard, C. M. (2003). Paisaje y señorío. La casa conventual de Ambel (Zaragoza): arquitectura e historia de las órdenes militares del Temple y del Hospital. Zaragoza: Institución Fernando el Católico (CSIC).

Hall, M. and Djerbib, Y. (2006). Moisture ingress in rammed earth: Part 3 - Sorptivity, surface receptiveness and surface inflow velocity. Construction and Building Materials 20(6), 384-395.

Heath, A., Lawrence, M., Walker, P. and Fourie, C. (2009). The compressive strength of modern earth masonry. Proceedings of the 11 th International Conference on Nonconventional Materials and Technologies (NOCMAT 2009), Bath, UK: BRE CICM.

Jaquin, P. (2008a). Analysis of historic rammed earth construction. (PhD., School of Engineering. University of Durham).

Jaquin, P. (2008b). Study of historic rammed earth structures in Spain and India. The Structural Engineer 86(2), 26-32.

Jaquin, P., Augarde, C. and Gerrard, C. (2007) Historic rammed earth structures in Spain, construction techniques and a preliminary classification. International Symposium on Earthen Structures, Bangalore, India. Bangalore: Interline Publishing.

Jaquin, P., Augarde, C. and Gerrard, C. (2008). A chronological description of the spatial development of rammed earth techniques. International Journal of Architectural Heritage 2(4), 377-400.

Jaquin, P., Augarde, C., Toll, D. G. and Gallipoli, D. (2009). The strength of rammed earth materials. Geotechnique 59(5), 487-490.

Maxwell, G. (2000). Lords of the Atlas. Morocco:
The rise and fall of the House of Glaoua (text written 1966). London: Cassel \& Co.

Pearson, G. T. (1997). Conservation of clay and chalk buildings. Shaftsbury: Donhead Publishing Ltd.

Walker, P., Keable, R., Martin, J. and Maniatidis, V. (2005). Rammed earth, design and construction guidelines. Watford: BRE Bookshop.

Warren, J. (1993). Earthen Architecture: The conservation of brick and earth structures. ICOMOS. 